\title{
Creep on a Composite Resin in Water
}

\author{
Susumu HIRANO and Tadashi HIRASAWA \\ Department of Dental Engineering, School of Dental Medicine, Tsurumi University \\ 2-1-3 Tsurumi, Tsurumi-ku, Yokohama 230
}

Received on January 28, 1989

Accepted on April 1, 1989

The compressive creep test of a composite resin $\left(0-3.5 \mathrm{~kg} / \mathrm{mm}^{2}\right.$ stress levels) was conducted in water for $500 \mathrm{~h}$. Linear regressions were obtained between the creep strains and the compressive stress levels at various hours. It is possible to predict the creep strain of the composite from the regression when it reaches water absorbed equilibrium after $500 \mathrm{~h}$.

The stress of the hygroscopic expansion was calculated from the linear regressions. The maximum stress due to the hygroscopic expansion of the composite was $0.74 \mathrm{~kg} / \mathrm{mm}^{2}$ at equilibrium of the water absorbed of the composite.

The linear regressions at several compressive stress levels were obtained within $30-50 \mathrm{hr}$ in the strain-log time diagrams.

Key words : Compressive creep, Composite resin, Stress of the hygroscopic expansion

\section{INTRODUCTION}

Dental composite resins are widely applied in dental restorations, but their mechanical properties have not been completely evaluated for the high stress bearing posterior restorations. For one approach in an attempt to understand how the properties could be improved, the creep behaviors have recently been investigated ${ }^{1-7)}$.

Ruyter and $\varnothing_{y s a e d^{1)}}$ investigated the compressive creep curves for several light cured composite resins characterized at several temperatures and stresses. Papadogianis, Boyer and Lakes ${ }^{2,3}$ investigated the modulus and the creep strain of the composites at various stresses by the tortional test method. Cook and Watts ${ }^{3)}$ explained the compressive strain of the composites to be finally linear against log time in compressive creep. Bapna, Mueller and Knoeppel $^{5)}$ tried to apply the creep compliance of the composites with the Voigt-Maxwell model. Ferracane, Matsumoto and Okabe ${ }^{6}$ considered the effects of filler concentration and the extent of conversion in composite resins to time-dependent deformation. Oden, Ruyter and $\emptyset_{\text {ysaed }}$ ) investigated the creep of the composites under static and dynamic compression in dry conditions and in water, and they showed that the creep deformation was of the same magnitude at the end of the test period, and also showed in water sorption, that the creep strain of the composite increased and the recovery of the composite decreased compared to the dry conditions.

In an oral environment the composite resins undergo hygroscopic expansion. This phenomenon takes a long time to reach equilibrium as water diffuses into the composite. The purpose of this study is to determine the behavior of the compressive creep of the composite in water and to determine the stress of the hygroscopic expansion of the composite from the 
creep curves obtained.

\section{MATERIAL AND METHODS}

A chemically cured composite resin* was used as the experimental material. Specimens were prepared following the manufacturer's recommended mixing ratio and were mixed for $30 \mathrm{~s}$. The mixture was injected by a syringe ${ }^{\#}$ into a mold of $2 \phi \times 10 \mathrm{~mm}$ and compressed with a glass plate. After 10 min the polymerized sample was removed and excess material was trimmed off. Then the sample was stored in an oven at $70-80^{\circ} \mathrm{C}$ for $24 \mathrm{~h}$. Thereafter it was stored in a decicater with silica gel at $37^{\circ} \mathrm{C}$ for one week.

The measurements of dimensional changes were made throughout the experiment by means of an electronic micrometer ${ }^{\$}$ attached to the apparatus. When the specimen was loaded, distilled water was immediately poured into the stainless steel vessel of the apparatus as shown in Fig. 1, and so the specimen was kept in distilled water at $37^{\circ} \mathrm{C}$.

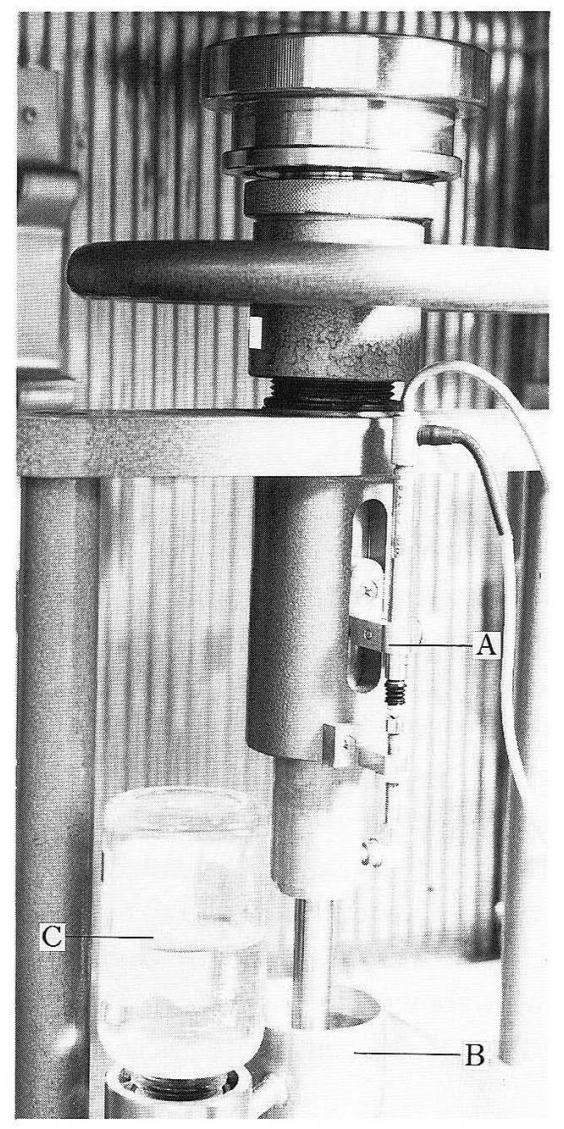

Fig. 1 Testing apparatus.
A : electoronic micrometer
B : stainless steel vessel
C: water reservior bottle

* ADAPTIC (Batch No. GGO19) J and J Dental Products Co. East Windsor, NJ USA

* CRC Syringe (No. 210001) Centrix Inc. Stanford, CT USA

$\$$ MU-Checker (Type 122 M) Mitutoyo MFG. Co. Tokyo 
The water uptake of the specimen seemed to reach equilibrium after $500 \mathrm{~h}$ as shown in Fig. 2. All the measurement were carried out for a period of $500 \mathrm{~h}$.

The loads applied were selected at 3,6 and $11 \mathrm{~kg}$ because of the specimen not being fractured or bent at these stresses.

Before every measurement a calibration was done using a $10 \mathrm{~mm}$ gauge block. The error of the apparatus was always within $\pm 2 \mu \mathrm{m}$. The measurement of $0 \mathrm{~kg} / \mathrm{mm}^{2}$ of the stress level of the creep was made only with the electronic micrometer ${ }^{8)}$ (measuring load $40 \mathrm{~g}$ ).

Three specimens in each condition were measured.

\section{RESULTS AND DISCUSSION}

The results obtained are given in Table 1 and Fig. 3. The dimensional change at $0 \mathrm{~kg} /$ $\mathrm{mm}^{2}$ compressive stress showed that the specimen expanded continuously after start of measurement due to the water absorption. The strain under the compressive stress in Fig. 3 represent the total strain of the specimen involving instantaneuos elastic, delayed elastic and plastic strain or creep strain associated with the stress, and also strain due to the water absorption. Thus some part of compressive strain might have been cancelled out by the hygroscopic expansion. The dimensional change at $1.0 \mathrm{~kg} / \mathrm{mm}^{2}$ was shown to be almost constant with time. The creep curve at $1.9 \mathrm{~kg} / \mathrm{mm}^{2}$ compressive stress showed the decrease in the specimen dimension after the start of the measurement, but the curve for the first few

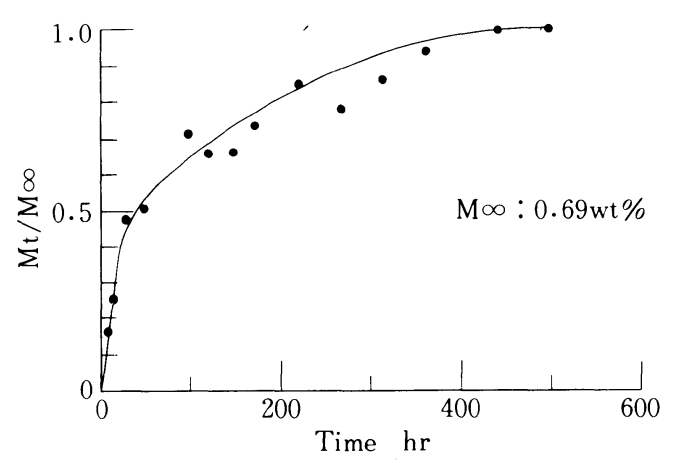

Fig. 2 The curve of the water uptake of the specimen.

Mt : Rate of the water uptake at time $t$

$\mathrm{M} \infty$ : Rate of the water uptake at equilibrium

Table 1 Results of the compressive creep of a composite obtained

\begin{tabular}{c|c|c}
\hline $\begin{array}{c}\text { compressive stress } \\
\left(\mathrm{kg} / \mathrm{mm}^{2}\right)\end{array}$ & $\begin{array}{c}\text { instantaneous strain } \\
(\%)\end{array}$ & $\begin{array}{c}\text { strain after 500hrs } \\
(\%)\end{array}$ \\
\hline 0 & & $0.29(0.03)$ \\
1.0 & $-0.10(0.02)$ & $-0.06(0.08)$ \\
1.9 & $-0.31(0.06)$ & $-0.50(0.05)$ \\
\hline .5 & $-0.48(0.06)$ & $-0.93(0.25)$ \\
\hline
\end{tabular}

( ) : standard deviation 
hours showed somewhat expansion of the specimen by the effect of the hygroscopic expansion of the specimen. The specimen dimension decreased uniformly with time at the stress level of $3.5 \mathrm{~kg} / \mathrm{mm}^{2}$.

The strain-log $t$ diagrams of the composite at several stress levels in Fig. 4 to Fig. 7 showed linear portion within $50 \mathrm{~h}$. These results coincided to the results of Cook and Watts ${ }^{4}$.

A linear regression was obtained between the creep strains after $500 \mathrm{~h}$ and the compressive stresses (Fig. 8);

$Y=0.2637-0.3543 X \quad(r=0.967)$

$Y$ : the creep strain after $500 \mathrm{~h}, X$ : the compressive stress, $r$ : coefficient of corelation.

From the above equation, it is possible to predict the strain for a given biting pressure ${ }^{9)}$ of the composite when it reaches water absorbed equilibrium after $500 \mathrm{~h}$. It can be assumed

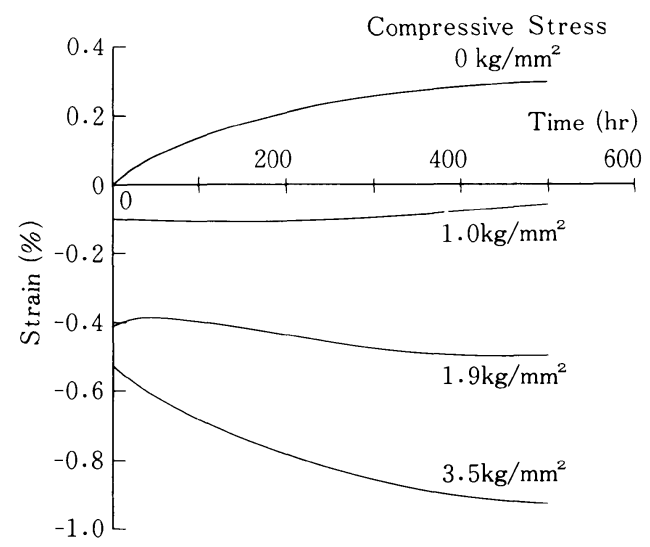

Fig. 3 Creep curves of a composite with various compressive stress levels.

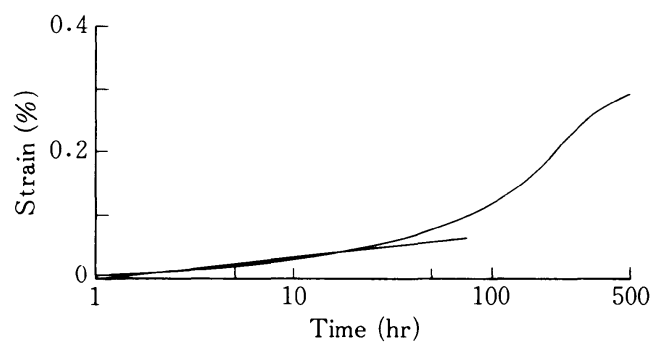

Fig. 4 Strain-log $t$ curve for a composite at $0 \mathrm{~kg} / \mathrm{mm}^{2}$ stress level. $30 \mathrm{~h}>: Y=0.0091+0.0390 \log X(r=-0.944)$

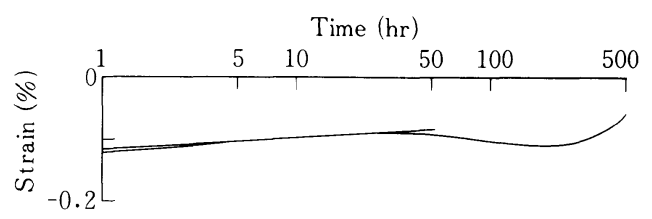

Fig. 5 Strain- $\log t$ curve for a composite at $1.0 \mathrm{~kg} / \mathrm{mm}^{2}$ stress level. $50 \mathrm{~h}>: Y=-0.1140+0.0198 \log X(r=-0.825)$ 


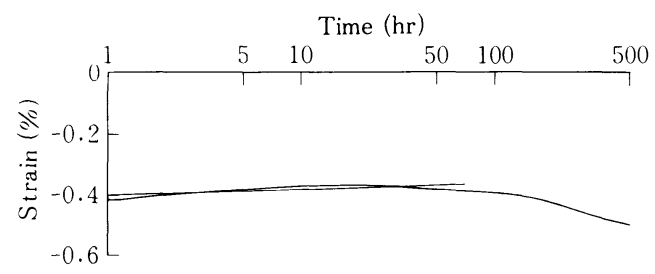

Fig. 6 Strain-log $t$ curve for a composite at $1.9 \mathrm{~kg} / \mathrm{mm}^{2}$ stress level. $50 \mathrm{~h}>: Y=-0.4035+0.0210 \log X(r=-0.743)$

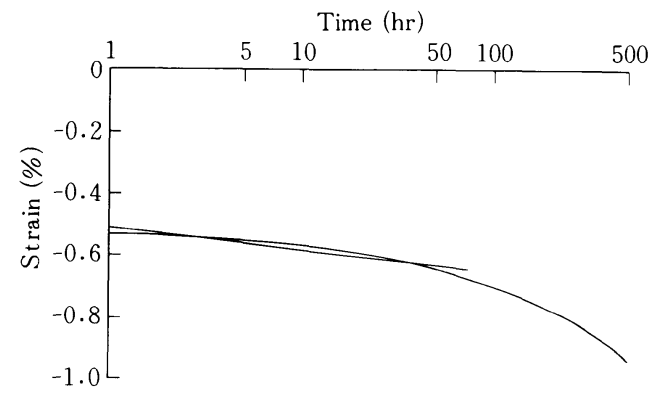

Fig. 7 Strain-log $t$ curve for a composite at $3.5 \mathrm{~kg} / \mathrm{mm}^{2}$ stress level. $75 \mathrm{~h}>: Y=-0.5144-0.0692 \log X(r=-0.953)$

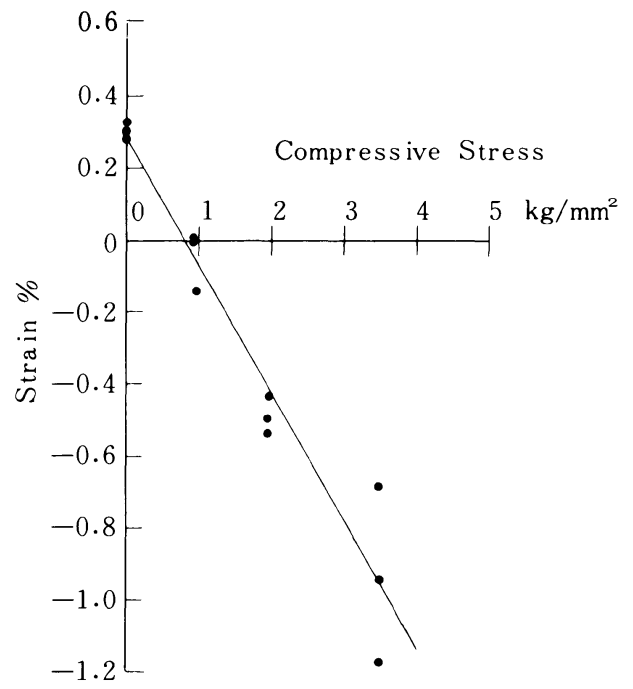

Fig. 8 Linear regression obtained between the strain after $500 \mathrm{~h}$ and compressive stress levels.

that the rate of the water uptake of a composite is constant in the range of these stress levels because the weight of the specimens after $500 \mathrm{~h}$ immersion was almost constant at every stress level in the preliminary experiment. Therefore linear regressions to calculate the stress due to the hygroscopic expansion of the composite from the creep curves were obtained between the total strains and compressive stress levels at various testing period, as shown 
Table 2 Linear regressions obtained and the stress of the hygroscopic expansion of the composite with various time

\begin{tabular}{|c|c|c|c|c|c|c|c|c|c|c|}
\hline $\mathrm{hr}$ & 1 & 3 & 5 & 10 & 20 & 50 & 100 & 200 & 400 & 500 \\
\hline A & 0.0039 & 0.0047 & 0.0232 & 0.0369 & 0.0802 & 0.0905 & 0.1285 & 0.2067 & 0.2520 & 0.2637 \\
\hline B & -0.1661 & -0.1676 & -0.1726 & -0.1808 & -0.2043 & -0.2184 & -0.2435 & -0.3244 & -0.3393 & -0.3543 \\
\hline & -0.942 & -0.954 & -0.955 & -0.961 & -0.961 & -0.963 & -0.960 & -0.990 & -0.965 & -0.967 \\
\hline $\begin{array}{l}\text { hygroscopic } \\
\text { expansion }\left(\mathrm{kg} / \mathrm{mm}^{2}\right)\end{array}$ & 0.02 & 0.03 & 0.14 & 0.20 & 0.40 & 0.41 & 0.53 & 0.64 & 0.74 & 0.74 \\
\hline
\end{tabular}

A : Constant, B : Regression coefficient, $r$ : Coefficient of correlantion $(\mathrm{Y}=\mathrm{A}+\mathrm{BX})$

Table 2. When $Y=0$ is introduced to the equation of Table 2, the stresses due to the hygroscopic expansion of the composite were given using the strain at various hours at every stress. Due to the increase in the rate of the water uptake of the composite, the stress of the hygroscopic expansion of the composite increased. The maximum hygroscopic expansion was estimated to be $0.74 \mathrm{~kg} / \mathrm{mm}^{2}$ when the water uptake of the composite had reached equilibrium. The stress due to the hygroscopic expansion of the composite is 3-6 times larger than the stress of the polymerization contraction ${ }^{10,11}$.

\section{CONCLUSIONS}

Linear regressions were obtained between the creep strains and the compressive stress levels in the composite. It is possible to predict the creep strain of the composite when it reaches water absorbed equilibrium after $500 \mathrm{hr}$.

The maximum stress of the hygroscopic expansion of the composite was also calculated to be $0.74 \mathrm{~kg} / \mathrm{mm}^{2}$ at equilibrium of the water uptake of the composite.

The linear regressions at several compressive stress levels were obtained within $50 \mathrm{hr}$ in the strain-log time diagrams.

\section{REFERENCES}

1) Ruyter, I. E. and Øysaed, H. : Compressive creep of light cured resin based restorative materials. Acta Odontol Scand 40: 319-324, 1982.

2) Papadogianis, Y., Boyer, D. B. and Lakes, R. S. : Creep of conventional and microfilled dental composites. J Biomed Mater Res 18: 15-24, 1984.

3) Papadogianis, Y., Boyer, D. B. and Lakes, R. S. : Creep of posterior dental composites. J Biomed Mater 19 : 85-95, 1985.

4) Cook, D. J. and Watts, D.C.: Time-dependent deformation of composite restorative materials in compression. J Dent Res 64(2): 147-150, 1985.

5) Bapna, M. S., Mueller, H. J. and Knoeppel, R. : Compressive creep of dental composites. J Dent Res 64(9) : 1179-1184, 1985.

6) Ferracane, J. L., Matsumoto, H. and Okabe, T.: Time-dependant deformation of composite resins compositional concideration. J Dent Res 64(11): 1332-1336, 1985.

7) Oden, A., Ruyter, I. E. and Øysaed, H.: Creep and recovery of composites for use in posterior teeth during static and dynamic compression. Dent Mater 4 : 147-150, 1988.

8) Hirasawa, T., Hirano, S., Hirabayashi, S., Harashima, I. and Aizawa, M. : Initial dimensional change of composites in dry and wet conditions. J Dent Res 62(1) : 28-31, 1983.

9) Hirano, S. and Hirasawa, T.: Biting pressure measured with pressure measuring sheet. J Jap Soc Apparat Mater 21 : 194-200, 1980. 
10) Bowen, R. L.: Adhesive bonding of various materials to hard tissues. VI. Forces developing in directfilling materials during hardening. J Amer Dent Assoc 74: 439-445, 1967.

11) Hegdahl, T. and Gjerdet, N. R. : Contraction stresses of composite resin filling matrials. Acta Odont Scand 35 : 191-195, 1977. 
に比ベクリープ破壊に対し長期間抵抗した。混合型高銅 アマルガムは，破壊時のクリープ值が試験したアマルガ ム中でもっとも大きかった。これはこのアマルガムが 連続的な荷重に対し他のアマルガムに比べてより柔軟性 があるということを意味している。破壊時間はクリープ
速度の逆数にほぼ比例し，クリープ速度が減少すると破 壊時間は急激に増加した。この結果は，以前に報告され た一定期間内のクリープ值とアマルガム修復物の辺縁破 折との相関をクリープ破壊の面から説明し，裏付けてい る。

\section{象牙質処理剂がレジンの接着性に与える影響について}

千葉幹男，伊藤和雄，和久本貞雄

昭和大学歯学部第二歯科保存学教室

Dentin cleanserによって象牙質の受ける変化が接着 性にいかなる影響を及ぼすかについて，リン酸，グリシ ン含有ピルビン酸, EDTAによる歯面清掃を行なった後 の象牙質の物理的特性を計測し，これらとレジンとの接 着性の相関を検討した。その結果，レジンと象牙質との 接着性は, cleanserによって象牙質に与える変化のうち Micro Vickers Hardness の低下と最も高い相関を示し
た。すなわち, cleanserによって残存象牙質硬さが $85 \%$ 以上に保たれるEDTA-2Naによる処理が最も良好な 接着性を示した。このことから，良好な接着性を得るた めには smear layerのみを除去し，象牙質には全く影響 を及ぼさない cleanserが理想的な材料であると結論付 けられた。

\section{Self Etching Dentin Primer の効果}

千木良尚志*，小池斗誌江*，長谷川篤司*，伊藤和雄*，和久本貞夫*，早川 徹**

*昭和大学歯学部第二歯科保存学教室

**日本大学松戸歯学部歯科理工学教室

$35 \% \mathrm{HEMA}$ 水溶液に希釈されたジカルボン酸また は，そのエステル構造物を含む市販及び試作の Self Etching Dentin Primerの効果を象牙質円柱窩洞内での 可視光線重合型コンポジットレジンのコントラクション ギャップの計測と象牙質平面に対する引つ張り接着強さ によって評価した。

試作した primer はすべて市販のリン酸エステル系ボ ンディング材と，また市販品のセルフエッチングタイプ の primer は付属のレジンモノマーを併用し, 全ての窩 洞および被着面には，市販の光重合型コンポジットレジ
ンを垻塞または接着させた。

その結果, HEMA にメタクリロキシエチルコハク酸 または,メタクリロキシエチルフタル酸を溶解した 2 種 類の試作 primer が，今回用いられたボンディイグ材の 象牙質に対する接着性を著明に向上させた。また，マレ イン酸を含む市販の primer は, 24 時間後の引つ張り接 着強さが $11.9 \pm 5.7 \mathrm{MPa}$ と高い值を示したが，コンポ ジットレジンと象牙質窩壁との適合性を改善することは できなかった。

\section{水中浸漬下におけるコンポジットレジンの圧縮クリープ}

平野 進，平沢 忠

鶴胃大学歯学部歯科理工学教室

コンポジットレジンの圧縮クリープを 4 種の異なる応 力 (圧縮応力 $0 \sim 3.5 \mathrm{~kg} / \mathrm{mm}^{2}$ ) で水中浸漬下で 500 時間
にわたり行なった。得られた 4 種のクリープ曲線から, 一定時間経過したときの各クリープひずみと圧縮応力と 
の間には一次回帰式が成立した。そのためコンポジット レジンの 500 時間後の吸水飽和状態になったときのク リープひずみは圧縮応力が分かれば予測可能となった。 またこの回帰式を使い, 各時間における吸水膨張応力を
求めた。最大吸水膨張応力はコンポジットレジンが吸水 飽和したときに得られ, その值は $0.74 \mathrm{~kg} / \mathrm{mm}^{2}$ であっ た。各応力下で得られたクリープ曲線をひずみ一対数時 間曲線で表すと, 初期の数十時間は直線となった。 